\title{
Deep Sylvian Meningioma in a 43-Year-Old Man: A Case Report
}

\author{
Jin Young Kim, Eun Joo Lee', Hyuk Won Chang', Hye-Ra Jung², Eal Maan Kim³, Sang Pyo Kim² \\ Departments of 'Radiology, ${ }^{2}$ Pathology and ${ }^{3}$ Neurosurgery, Keimyung University, Dongsan Medical Center, Daegu, Korea
}

Deep sylvian meningioma is a rare form of meningiomas. So far, only 4 cases including the present one have been reported in South Korea. A 43-year-old man without any previous medical history presented to our hospital with seizure. There was a rim enhancing mass in the right deep sylvian fissure without dural attachment on magnetic resonance images. Surgical resection of the mass revealed the lesion to be a meningioma in this patient.

Index words : Brain · Meningioma · Magnetic resonance imaging (MRI)

\section{INTRODUCTION}

Meningiomas are common benign brain tumor which arise from the arachnoid cap or meningoepithelial cells usually located in the meningeal arachnoid area. These tumors exhibit dural attachment signs on imaging studies (1). A meningioma without dural attachment is a rare type of meningioma, and deep sylvian meningioma is one of subtype of meningiomas without dural attachment. In this study we present a case of deep sylvian meningioma.

\section{CASE REPORT}

A 43-year-old man visited our hospital emergency center with a new onset seizure. The patient had no significant past medical history. The patient had immediately undergone computed tomography (CT)

- Received; August 22, 2013 - Revised; October 10, 2013

- Accepted; October 23, 2013

Corresponding author: Hyuk Won Chang, M.D.

Department of Radiology, Keimyung University, Dongsan Medical Center, 56 Dalsungro, Jung-gu, Daegu 700-712, Korea.

Tel. 82-53-250-7767, Fax. 82-53-250-7766

E-mail : hyukwonchang@korea.com and magnetic resonance imaging (MRI). The CT revealed a $15 \times 16 \times 16 \mathrm{~mm}$ rim enhancing mass located in the right deep sylvian fissure with minimal calicifications. The MRI revealed the mass as having iso-signal intensity in T1 and T2 weighted images (WI), and rim enhancement in gadolinium-enhanced T1WI with peritumoral edema. No dural tail sign was noted, which is a characteristic finding of extra-axial tumors (Fig. 1). Our first impression was a metastatic mass, with decreased certainty for brain tumors such as glioma or lymphoma.

The patient underwent a surgical resection of the tumor mass, which was found to be an extra-axial mass located in the deep sylvian fissure. There was no dural attachment.

The pathologic diagnosis of mass confirmed lymphoplasmacyte-rich type meninigoma (WHO grade I) (Fig. 2). The less enhanced central portion was identified as central hyalinizing or sclerotic area, intermingling with clusters of meningothelial like cells. The immunohistochemistry profile showed positive staining of epithelial membrane antigen (EMA) and vimentin.

The patient's post-operative course was uneventful, and has returned to normal activities without any neurologic deficiencies. A follow-up gadolinumenhanced MRI showed about $5 \mathrm{~mm}$ sized residual mass in the right deep sylvian fissure, which remained 
unchanged for 4 years after the surgery.

\section{DISCUSSION}

Meningioma is a common brain tumor which represents about $15 \%$ of primary intracranial tumors in adults. Most meningiomas present with typical dural tail sign in imaging studies, since it originates from arachnoid cap or meningothelial cells (1). A meningioma without dural attachment was first identified by Cushing and Eisenhardt (2). Furthermore, Zhang et al. (1) had classified supratentorial meningiomas without dural attachment into five types: intraventricular meningioma, pineal region meningioma, deep sylvian meningiomas, intra-parenchymal or subcortical meningiomas, and others. These investigators also classified infratentorial meningiomas without dural attachment into four types: intraventricular, inferior telachoroidea, cisterna magna, and intraparenchymal types.
Deep sylvian meningioma probably arise from the arachnoid cap cells in the arachnoid and pia of the

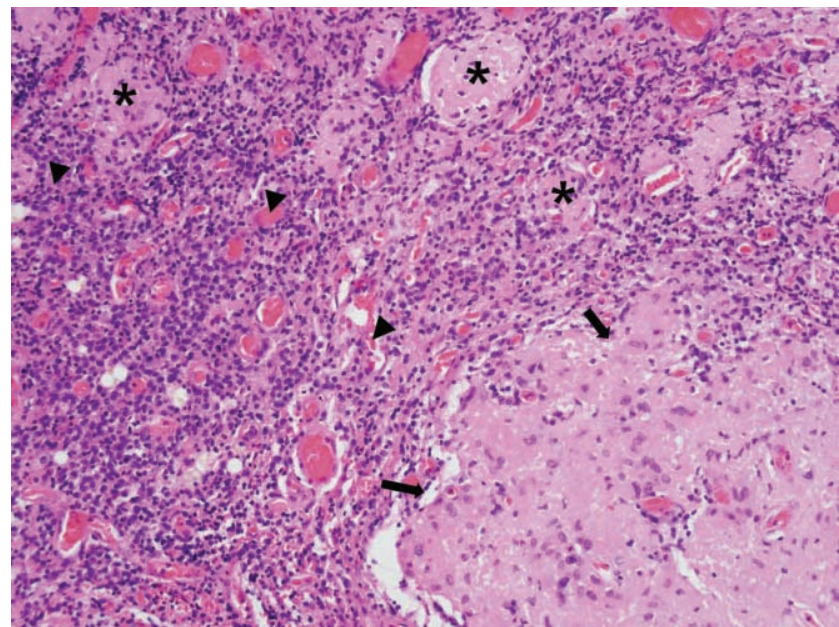

Fig. 2. The mass showing meningothelial proliferative lesion (arrows) and surrounding lymphoplasmacytic infiltrative background (arrowheads). Scattered meningioma component are noted (asterixs)

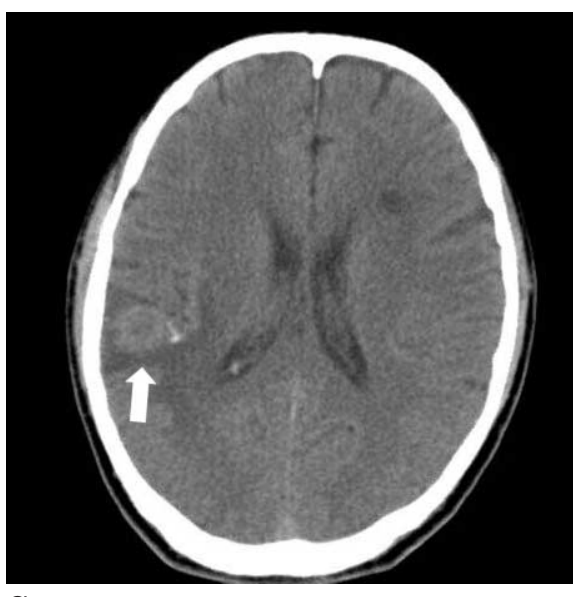

a

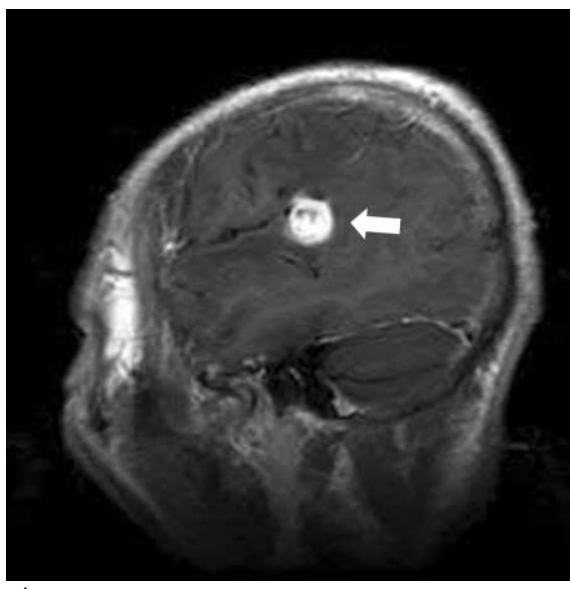

d

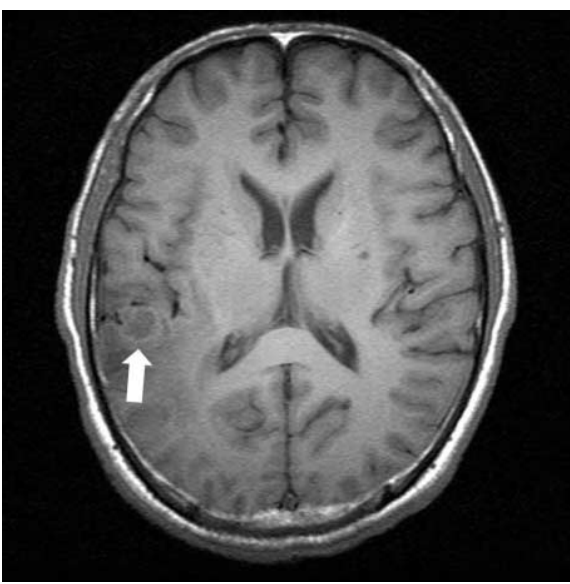

b

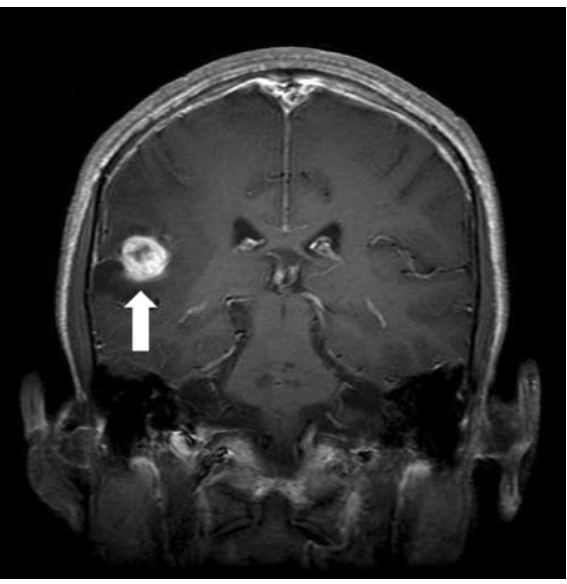

e

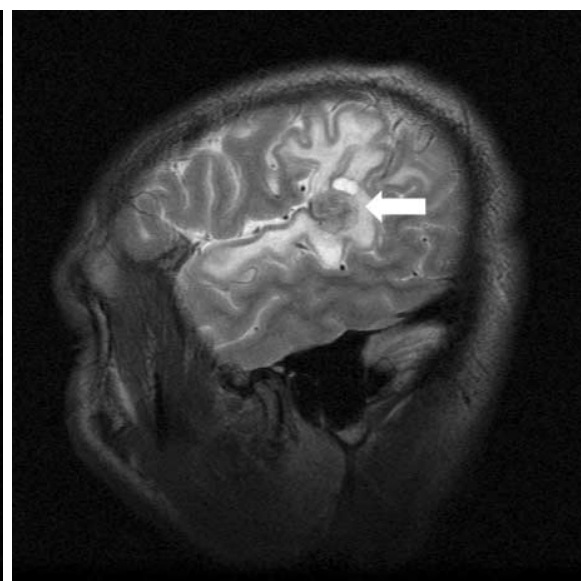

C

Fig. 1. The initial CT (a) study revealed a 15 $\times 16 \times 16 \mathrm{~mm}$ rim enhancing mass located in the distal portion of right sylvian fissure with minimal calicifications. On MRI study, this lesion was found to have iso-signal intensity in T1 (b) and T2 (c) weighted images with surrounding adjacent edema. In T1 contrast phase ( $\mathbf{d}, \mathbf{e})$, the mass showed ring like enhancement. 
Table. 1 Cases of Deep Sylvian Meningiomas from South Korea

\begin{tabular}{|c|c|c|c|c|c|c|c|c|c|c|}
\hline $\begin{array}{l}\text { Author } \\
\text { (year) }\end{array}$ & $\begin{array}{l}\text { Age/ } \\
\text { Sex }\end{array}$ & $\begin{array}{c}\text { Clinical } \\
\text { Presentation }\end{array}$ & Location & $\begin{array}{c}\text { CT } \\
\text { Finding }\end{array}$ & $\begin{array}{c}\text { MRI } \\
\text { Finding }\end{array}$ & $\begin{array}{l}\text { Dural } \\
\text { tail sign }\end{array}$ & Edema & OP & $\begin{array}{l}\text { Pathologic } \\
\text { Type }\end{array}$ & F-U \\
\hline $\begin{array}{l}\text { Cho } \\
\text { et al } \\
1990(4)\end{array}$ & $\begin{array}{c}2 \mathrm{yrs} / \\
\mathrm{M}\end{array}$ & Seizure & $\begin{array}{l}\text { Deep } \\
\text { sylvian } \\
\text { fissure }\end{array}$ & $\begin{array}{l}\text { Heterogeneous } \\
\text { hyperdense with } \\
\text { homogeneous } \\
\text { enhancement }\end{array}$ & NS & $\mathrm{N}$ & $\mathrm{Y}$ & Total & Transitional & $\begin{array}{l}2 \text { yrs with } \\
\text { no } \\
\text { recurrence }\end{array}$ \\
\hline $\begin{array}{l}\text { Moon } \\
\text { et al } \\
2003(5)\end{array}$ & $\begin{array}{c}36 \mathrm{yrs} / \\
\mathrm{M}\end{array}$ & Seizure & $\begin{array}{l}\text { Deep } \\
\text { sylvian } \\
\text { fissure }\end{array}$ & NS & $\begin{array}{c}\text { T1: low } \\
\text { T2: iso } \\
\text { T1c+: homogeneous } \\
\text { enhancement }\end{array}$ & $\mathrm{N}$ & $Y$ & Subtotal & Transitional & $\begin{array}{c}\text { No } \\
\text { complications }\end{array}$ \\
\hline $\begin{array}{l}\text { Chae } \\
\text { et al } \\
2012(6)\end{array}$ & $\begin{array}{c}69 \mathrm{yrs} / \\
\mathrm{M}\end{array}$ & $\begin{array}{c}\text { No } \\
\text { symptom }\end{array}$ & $\begin{array}{l}\text { Deep } \\
\text { sylvian } \\
\text { fissure }\end{array}$ & $\begin{array}{l}\text { Calcification } \\
\text { with } \\
\text { enhancement }\end{array}$ & $\begin{array}{l}\mathrm{T} 1, \mathrm{~T} 2: \text { iso to low } \\
\mathrm{T} 1 \mathrm{c}+\text { : heterogeneous } \\
\text { enhancement }\end{array}$ & N & $\mathrm{Y}$ & Subtotal & Psammomatous & NS \\
\hline $\begin{array}{l}\text { Present } \\
\text { case }\end{array}$ & $\begin{array}{c}43 \mathrm{yrs} / \\
\mathrm{M}\end{array}$ & Seizure & $\begin{array}{l}\text { Deep } \\
\text { sylvian } \\
\text { fissure }\end{array}$ & $\begin{array}{l}\text { Calcification } \\
\text { around } \\
\text { tumor }\end{array}$ & $\begin{array}{c}\text { T1: iso } \\
\text { T2: iso } \\
\text { T1c+: rim } \\
\text { enhancement }\end{array}$ & $\mathrm{N}$ & $\mathrm{Y}$ & Subtotal & $\begin{array}{l}\text { Lympho- } \\
\text { plasmacyte } \\
\text { rich }\end{array}$ & $\begin{array}{l}4 \text { yrs with } \\
\text { no } \\
\text { recurrence }\end{array}$ \\
\hline
\end{tabular}

Note-- OP, operation; F-U, follow up; yrs, years; Mo, months; M, male; F, female, CT, Computed tomography; MRI, magnetic resonance imaging; NS, not stated; T1, T1 weighted image; T2, T2 weighted image; T1c, T1 weighted contrast phase; iso, iso-intensity; low, low-intensity; high, high-intensity; Y, yes; N, no; Total, total resection

sylvian fissure and the Virchow-Robin space of the middle cerebral artery branches (3). To the best of our knowledge, only 4 cases of deep sylvian meningioma including the present case have been reported in South Korea (Table 1). Additionally, meningiomas without dural attachment have been reported for a total of only 8 cases in Korea (7-9). In worldwide, about 28 cases of deep sylvian meningioma including our case have been reported $(1-6,10)$.

Meningiomas without dural attachment have been reported to mainly affect young adults with a slight male predominance (mean age of 26.5 years and 1.39 times more prevalent in males). The most common clinical presentation is seizure, and most patients are reported to have good prognosis after surgery (3). Radiologic findings are variable for this rare entity, and pre-operative correct diagnosis is difficult. On MRI, the mass is more frequently described as having iso- or low-signal intensity on both T1WI and T2WI with intense homogeneous enhancement and peritumoral edema (3). Sometimes the mass shows a calcification on noncontrast CT. However, these findings are nonspecific, and the lesion may be confused with glioma, metastasis, lymphoma, tuberculous granuloma, cavernous angioma, and cranio- pharyngioma.

Pathologically, the lympoplasmacyte rich type (WHO grade1) deep sylvian meningioma has never been reported.

Table. 1 summarizes the 4 reported cases in Korea, showing certain agreements with radiologic findings from previous reports.

The preoperative diagnosis of deep sylvian meningioma is very difficult. However, a deep sylvian meningioma should be considered when a well enhanced mass is observed in the fissure, even in the absence of a dural tail sign.

\section{References}

1. Zhang J, Chi LY, Meng B, Li F, Zhu SG. Meningioma without dural attachment: case report, classification, and review of the literature. Surg Neurol 2007;67:535-539

2. Cushing H, Eisenhardt L. Meningiomas. Their Classification, Regional Behaviour, Life History, and Surgical End Results. New York: Hafner Publishing Company; 1969. p. 133-68

3. Cecchi PC, Campello M, Rizzo P, Mair K, Schwarz A. Atypical meningioma of the sylvian fissure. J Clin Neurosci 2009;16:1234-1239

4. Cho BK, Wang KC, Chang KH, Chi JG. Deep sylvian meningioma in a child. Childs Nerv Syst 1990;6:228-230

5. Moon BJ, Choi JY, Park YG, Chung SS. Deep sylvian meningioma: case report. J Korean Neurosurg Soc 2003;33:218- 
221

6. Chae MP, Song SW, Park SH, Park CK. Experience with 5aminolevulinic acid in fluorescence-guided resection of a deep sylvian meningioma. J Korean Neurosurg Soc 2012;52:558-560

7. Jung YS, Song YJ. Meningioma in a 20-month-old boy. J Korean Neurosurg Soc 2012;51:219-221

8. Choi YM, Kim TY, Kim JM. A case of meningioma in temporo- occipital lobe without dural attachment in a 14-yer-old girl: case report. J Korean Neurosurg Soc 1996;25:1101-1107

9. Ko BS, Jung S, Jung TY, Kim IY. Intraparenchymal sylvian fissure meningioma. J Korean Neurosurg Soc 2007;41:120-122

10. Aras Y, Akcakaya MO, Aydoseli A, Izgi N. Staged surgery for sylvian fissure meningiomas without dural attachment: report of two cases. Clin Neurol Neurosurg 2013;115:1527-1529

\title{
43세 남자에게서 발생한 심부실비우스열뇌수막종: 증레보고
}

\author{
${ }^{1}$ 계명대학교 동산병원 영상의학과 \\ ${ }^{2}$ 계명대학교 동산병원 병리과 \\ ${ }^{3}$ 계명대학교 동산병원 신경외과 \\ 김진영 ${ }^{1} \cdot$ 이은주 ${ }^{1} \cdot$ 장혁원 ${ }^{1} \cdot$ 정혜라 $^{2} \cdot$ 김일만 $^{3} \cdot$ 김상표 $^{2}$
}

심부실비우스열뇌수막종은 뇌수막종의 드문 형태이다. 본 증례를 합하여 한국에서 총 4증례가 보고 되었다. 이전 병력이 없던 43세 남자가 경련발작을 주소로 본원에 내원하였다. 자기공명영상에서 오른 심부실비우스열에 테두리가 조영증강되는 종괴가 발견되었고 경막과의 연결성은 없었다. 수술적 제거 후 심부실비우스뇌수막종으로 진단되었다.

통신저자 : 장혁원, (700-712) 대구시 중구 달성로 56, 계명대학교 동산병원 영상의학과

Tel. (053) 250-7767 Fax. (053) 250-7766 E-mail: hyukwonchang@korea.com 